\title{
The moral minefield: Legal and social issues of tobacco and liquor marketing
}

\author{
Diane Sacks and R. Abratt \\ Graduate School of Business Administration, University of the Witwatersrand, Braamfontein
}

This article focuses on the liquor and tobacco industries. These two industries were chosen because they have been catapulted into the foreground of the societal marketing polemic as a result of the widespread agreement that the consumption of their products can cause serious damage to personal and social welfare. The legal and social context in which tobacco and liquor products are marketed internationally and in South Africa are discussed. Some general conclusions are drawn from this review which will have implications not only for the two industries involved, but society as a whole.

S. Afr. J. Bus. Mgmt. 1986, 17: $182-190$

Hierdie artikel werp lig op die drank- en tabaknywerhede. Hierdie twee nywerhede is gekies vanwee die bemarkingspolemiek wat daar vanuit die oogpunt van die gemeenskap rondom hierdie nywerhede bestaan. Die polemiek spruit voort uit die wydverspreide aanvaarding dat die produkte van hierdie nywerhede ernstige skade aan persoonlike en sosiale welsyn kan aanrig. Die wetlike en die sosiale raamwerk waarbinne tabak- en drankprodukte internasionaal; sowel as in Suid-Afrika bemark word, word bespreek. Enkele algemene gevolgtrekkings word uit hierdie oorsig gemaak, wat nie net implikasies vir beide nywerhede inhou nie, maar vir die gemeenskap as 'n gehoel.

S.-Afr. Tydskr. Bedryfsl. 1986, 17: $182-190$

\section{Diane Sacks and R. Abratt*}

Graduate School of Business Administration,

University of the Witwatersrand, P.O. Box 31170, Braamfontein, 2017 Republic of South Africa

*To whom correspondence should be addressed

\section{Introduction}

The purpose of this article is to provide a review of the legal and social context in which tobacco and liquor products are marketed internationally and in South Africa.

The South African situation will be discussed in greater detail than will the international situation. Thus current legal and voluntary regulations concerning the marketing of cigarettes and alcoholic beverages in South Africa will be reviewed, as will the current social demands and pressures being placed on the two industries (as ascertained mainly from media releases).

\section{The international scene \\ The tobacco industry}

Although the injurious effects of cigarette smoking on health have been a matter of public concern for many decades, it was only with the rise of New Consumerism in the 1960s that the issue was catapulted into the public spotlight. Since then the tobacco industry world-wide has come under increasing attack, not only from consumer activists, governments and health bodies, but also from an increasingly aware, knowledgeable and articulate public.

The vociferousness and intensity of these attacks has been fuelled by the image of smokers created by the marketers and especially advertisers - of cigarettes, traditionally and still today, one of the most heavily and consistently advertised of all consumer products.

'Image creation of one type or another dominates tobacco advertising; identifying segments dominates the marketing' (Sobczynski, 1983:14). This is so because 'the cigarette belongs to a class of product in which it is difficult to differentiate one brand from another by attributes: hence attributes are ascribed largely through reference group appeal built up by advertising' (Enis \& Cox, 1981). As Cullinan, Chief Executive Officer of Philip Morris Inc. put it: 'We're a marketing organisation. Our success is related to our ability to market and merchandise, using consistent and integrated themes aimed at the growth segments of the market' (Strickland \& Thompson, 1982:233). Significantly, the growth segments in recent years have been the young female market and the Third World market (Jacobson, 1983). And this is the basis of one of the major criticisms directed at the cigarette industry that it deliberately nurtures new and often vulnerable markets: 'The tobacco manufacturers have, of course, a gift in their hands. Since the 1920 s girls have identified smoking with independence. Emancipation bought at the price of a packet of cigarettes might throw in a case of cancer for nothing but who cares ...?' ('Smoking Habit', 1985). This article in 
The Star gives the example of British American Tobacco which, in 1982, budgeted R700 000 for the launch of a cigarette aimed exclusively at the women's market. This budget, the article stated, equalled the amount the Health Education Council in Britain had available for all its activities for an entire year. Thus tobacco companies are criticized for the vast resources they commit and the methods they use to obtain new markets. They are criticized for the use of subtle techniques of persuasion - techniques which all too often rely upon the exploitation of human frailties, emotions, vulnerabilities and ignorance to achieve their undoubted success.

Thus, as the creativity and ingenuity of cigarette marketers has reached new heights, so too has the ire of its opponents. Cigarette companies are accused of intellectual dishonesty (Blakeney \& McKeough, 1984) in that they use advertising themes which deliberately - if implicitly - confuse the smoking-health issue. This is done primarily by portraying male smokers as virile, handsome and healthy, or even distinguished middle-aged smokers still in the glow of health despite years of smoking (Teel, Teel \& Bearden, 1979:48). Thus, for example, the US Federal Trade Commission, in its staff report on the cigarette advertising investigation of May 1981, concluded: '(Cigarette advertisements) associate smoking with good health, youthful vigor, social and professional success and other attractive ideas, individuals and activities that are both worthy of emulation and distant from concerns relating to health . . . Thus the cigarette is portrayed as an integral part of youth, happiness, attractiveness, personal success and an active, vigorous, strenuous life style' (Sobczynski, 1983:16).

The strong opposition to the marketing - and especially advertising - methods of cigarette manufacturers is clearly reflected in the increasing amount of regulation pertaining to the marketing of cigarettes. The situation in the USA over the past few decades is illustrative. In 1964, the release of the Surgeon General's report on the injurious effects of smoking on health acted as a catalyst for the wave of public regulation which was about to begin. Thus in 1965 a health warning label was required on cigarette packs. In 1971 a health warning was also required in each cigarette advertisement and in terms of the 'Fairness Doctrine' the Federal Communications Commission ruled in 1967 that free advertising time was to be guaranteed to anti-smoking groups to present the 'other side' of the smoking story (Doron, 1979b:49). Later this was extended by the ruling that anti-smoking commercials had to be carried in prime time as well as on children's programmes and that a ratio of five cigarette advertisements to one antismoking advertisement had to be maintained (Teel, et al. 1979:45). Shortly thereafter - in April 1970 - the Public Health Cigarette Smoking Act prohibited radio and television advertising for cigarettes to be effective from 2 January 1971 . This also signalled the end of the anti-smoking advertisements as the 'Fairness Doctrine' was no longer applicable in the absence of advertisements for cigarettes. Since October 1985 a new set of health warnings has been required on all cigarette packages and in all advertising (Wilkie, 1985:93). These warnings are $50 \%$ larger, more prominently displayed, and more specific than those in the past. Four different warnings are required to be rotated in terms of the Comprehensive Smoking Education Act:

- Surgeon General's warning: Smoking causes lung cancer, heart disease, emphysema, and may complicate pregnancy.

- Surgeon General's warning: Cigarette smoke contains carbon monoxide.
- Surgeon General's warning: Quitting smoking now greatly reduces serious risks to your health.

- Surgeon General's warning: Smoking by pregnant women may result in fetal injury, premature birth and low birth mass.

These replace the previous broad statement: Warning: The Surgeon General has determined that cigarette smoking is dangerous to your health.

Today restrictions of varying degrees are in force in most countries of the Western world. Thus, for example, television bans on cigarette advertising have been in force in New Zealand since 1962, the UK since 1965, West Germany and Canada since 1972, and Australia since 1976. Total bans on cigarette advertising have been in existence in Italy since 1962, Thailand since 1969, Singapore since 1970, Iceland since 1972, Norway since 1975 and Finland 1978 (Boddewyn, 1983:6 and International Advertising Association, 1983:10). In most centrally planned economies such as the USSR, Czechlosovakia, Hungary and East Germany there is a complete and effective ban upon all forms of tobacco advertising.

Although the motives for imposing advertising restrictions have differed from country to country, in those countries where the purpose has been to reduce the level of consumption, such bans have not always had the desired effect. Thus Doron (1979b:49 - 50) pointed out that in the USA, the health warning on cigarette packets has in fact been 'a boon of sorts to the industry, now legally protected by the warning label against potential liability suits for damages to health arguably caused by cigarettes.'

Also, it was found that whilst advertising bans had no significant impact on consumption levels, the anti-smoking advertisements definitely lowered consumption levels. Thus it was ironic that the 1971 television ban on cigarette advertising in the USA - which also ended the anti-smoking advertisements on television - had greater negative consequences for those opposed to smoking than for the cigarette industry itself (Doron, 1979b:51). In addition, the television ban gave existing cigarette manufacturers lasting control over the market and yet it didn't appear to have any effect on the growing number of young smokers (Teel, et al., 1979:46 and Doron, 1979b:52). Thus some predicted at the time that the ban would give 'sweeping carte blanche protection (to) a particular industry' and in effect end the debate on the hazards of smoking (see Doron, 1979b:52). Although the latter prediction has not come about, Doron was quite categorical: 'If public interest was to be harmed by an increase in smoking, then public interest was not served by this public regulation' (1979b:52). And elsewhere he made his view on the role of government quite clear: 'It is . . . up to the consumer to make a choice between smoking or not smoking. The role of government should be simply to make that choice an informed and educated one' (1979a:168). The effects of advertising bans on cigarette consumption have been extensively researched and documented. Many - even though some of them have a stake in continued advertising - put forward a strong case to refute the effectiveness of such bans in reducing consumption levels (see International Advertising Authority, 1983; Boddewyn, 1983; Littlechild, 1982:31; Metra Consulting Group Ltd, 1980). However the issue is by no means decided. Thus while Teel, et al. (1979) concluded that the US television advertising ban was ineffective, they did mention that the true effectiveness of such a course of action may only be estimated in the long term. They also pointed out that one of the reasons for the ban's failure was the fact that the print media had nroven to be a 'more than adequate substitute' for television 
and radio advertising. Thus advertising per se had not stopped. Furthermore, advertising bans have been effective in some countries, for example, Norway (Lessof, 1983), and in the USA, despite the initially disappointing reports on the effect of the television advertising ban, consumption levels have been declining since 1981 as a result of the persistent public outcry against cigarette smoking (Rudolph, 1985:76). The difficulty arises not only in attempting to take account of all the many factors affecting consumption levels either way, but also in predicting what would have happened to consumption levels in the absence of advertising restrictions. Thus although it is difficult to draw definite conclusions, it can be said that advertising regulations such as bans, health warnings on advertisements, etc., are only one possible solution to an extremely complex problem and, although they may not always prove to be as effective as could be desired, they certainly play a role in changing attitudes, values and finally, behaviour (Wilkie, 1977:32 - 33).

Although bans on cigarette advertising are commonplace today, the recent trend in regulation has been to restrict or ban the actual smoking of cigarettes. Thus in the USA 38 states and 250 cities have banned smoking in public places. In parts of Florida smokers in the workplace are required to ask the permission of every other employee in their workplace before smoking and many major US companies have either partial or total bans on smoking (Wallace, 1986). In Britain too, many leading companies have bans on smoking, as do a number of public authorities - and in fact a Bill which would compel employers to provide smoking and nonsmoking areas in workplaces is to come before the House of Commons this year.

Another recent phenomenon is the spate of product liability cases which, despite the health warning on cigarette packets, are being brought against tobacco companies - particularly in the USA ('Court Battle', 1985). As yet, none have succeeded.

Meanwhile the tobacco industry has not, in the wake of increasing regulation and public hostility, remained silent. It has vigorously opposed all attempts to ban or restrain its marketing efforts, consistently denying that its advertising campaigns attempt to increase the total cigarette market. It alleges that its advertising is designed to induce brandswitching, i.e. advertising is used as a 'tool for competition over market share and not for market expansion' (Doron, 1979b:50; See also International Advertising Association, 1983:6 and Fenn, 1983:14). It has also consistently denied and publicized its denials - that cigarette smoking actually causes lung cancer. In the USA the industry has established the Tobacoo Institute as its lobbying arm and this organization mounts massive advertising campaigns to present the industry's response to the many accusations levelled at it and smoking in general (see 'New Woes', 1983:11). It has sponsored and publicized research which presents the 'beneficial' effects of smoking or disproves claims to the contrary. And in recent years, as the concern about 'passive smoking' (smoke inhalation by non-smokers) has manifested itself in the banning of smoking in many public areas, the industry has responded to its increasingly threatened position by becoming more aggressive in its own defence. This stance has been sharply criticized by many who feel that the industry, acting in its own self-interest, should not involve itself in the debate on the merits and demerits of smoking, particularly because it believes that ultimately, 'smoking is a question of individual responsibility' (RJ Reynolds Tobacco Company quoted in the Evening Post, 'Tobacco Firm not Guilty', 1985). Thus Weis
(1985:37) commented: 'For all of its libertarian bantering about individual rights . . . the tobacco industry seems not to have learned that its own business is selling tobacco products ... not forcing its own social values on a free society ...'

In recent years the smoking debate has gradually shifted in emphasis from health issues to social issues and, with the increasing involvement of the tobacco industry itself, the tenor of the debate has become decidedly political, and the debate itself a game of power and manipulation.

From a review of recent literature in the smoking debate the following points can be noted:

(i) There is a growing belief that the tobacco industry is a dying one. This belief is strengthened by the aggressive diversification of major cigarette manufacturers which, however, flatly deny the validity of this belief. (See Rudolph, 1985:76 and Blum \& Rosenberg, 1983).

(ii) There is a call for even greater restrictions on the marketing and consumption of cigarettes, for example:

- withdrawal of sport sponsorships by tobacco companies ('Tobacco Firms Face Sponsorship Threat', 1985);

- increases in cigarette taxes (Lessof, 1983);

- stricter package warnings, extensions of advertising bans to include every possible type of advertising (see Cummins, 1984);

- prohibition of smoking everywhere unless specifically permitted (Kahn, 1983).

(iii) There is a change in public attitudes from regarding smoking as the norm - and therefore socially acceptable - to regarding non-smoking as the norm and smoking as socially unacceptable ('New Woes', 1983:11).

(iv) There is growing public disapprobation at the manner in which tobacco companies are focusing on developing nations to prop up flagging sales in First World countries (see Jacobson, 1983 and Rudolph, 1985:77).

(v) Growing politicization of the debate as anti-smoking groups see the tobacco industry as being the real enemy, rather than smokers or cigarettes ('Smoking - changes in Emphasis', 1983:803).

\section{The liquor industry}

The marketing of liquor products, like that of cigarettes, is heavily reliant on image creation and reference group influence (Enis \& Cox, 1981:215). Thus the advertising of liquor tends to be similar in theme to cigarette advertising, associating the consumption of liquor with youth, glamour and success.

Despite the many similarities in the two industries, there are notable differences in their situations.

Whereas tobacco was only introduced into the Western world in the 16th century (Morkel, 1982:7), the consumption of alcoholic beverages has been an integral part of Western civilization for several thousand years (Phillipson, 1981:27). And whilst tobacco smoking has always been simply a pleasurable personal habit, the role of alcohol in society has ranged from its use as a medicinal and therapeutic remedy to its use as a source of flavour and nutrition in food, and as part of the rituals of many religions of the world. In addition to its deeper roots and more extensive use in society, and because of its very different physiological and psychological effects on the user, it has also been responsible for much of the misery, degradation and tragedy in human life.

Unlike cigarette smoking - which affects primarily the smoker and those in close proximity to him - alcohol abuse affects not only the abuser, but all too frequently also his family and friends, as well as countless other innocent 
individuals who are injured in alcohol-related accidents, such as motor accidents caused by drunken driving. Thus the negative consequences of alcohol abuse are far more serious and far-reaching in modern society than are those of smoking. Another important point of difference is that whilst cigarette smoking per se is objected to by much of society, because not even the minimal use of the product is regarded as beneficial without exacting some cost to one's health, the problem with alcohol arises not from its use (it has been proven to be beneficial to health if used in moderation), but from its abuse. Indeed, its moderate and temperate use is regarded as 'a lawful comfort which God alloweth to all men' (Howie, quoted in Wilcox, 1985:34). For all these reasons, alcohol abuse is regarded more as a social problem in which business should play its part in alleviating, rather than a societal problem created by business itself.

Thus whereas the smoking issue is becoming a political one (with the tobacco industry and its opponents lined up in open confrontation), alcohol abuse is still largely a subject of medicine and sociology - although the liquor industry is increasingly being included in discussions of the problem as those seeking to combat it adopt a more holistic approach. However, while the co-operation of the industry is being sought - the relationship between the industry and those fighting alcohol abuse is not nearly as adversarial and unequivocably confrontational as is the case in the cigarette industry. The liquor industry is still accorded a legitimate role in society by most, but it is asked to stress the moderate and responsible use of its products, whereas the tobacco industry is accorded no such legitimacy and many would choose to see its demise.

In the light of the above observations, it is not surprising to note that the public campaign and opposition to alcohol consumption and the liquor industry - whilst certainly present - has not reached nearly the same intensity, received the same media exposure, or produced the same degree of acrimony and hostility as has the campaign against tobacco smoking. However, the public attitude towards alcohol consumption tends to pass through different phases, and the move towards greater regulation of marketing, distribution and consumption of alcoholic beverages has certainly gained momentum over the past decade or two, after a period of relative laxity during which consumption and its concomitant problems rose steadily.

Thus growing public awareness and societal concern has caused the wheel to turn once again in the direction of increasing controls and restrictions.

Thus Wilcox (1985:33) wrote: 'During recent years, various consumer groups in many Western nations have begun to exhibit a growing concern over alcohol consumption . . . The main target of this movement is alcoholic beverage advertising to which the various collective groups attribute the responsibility for increasing consumption . . . with multimillion dollar advertising and promotion campaigns.' This growing concern is exemplified by the formation of lobby groups such as MADD (Mothers against Drunk Driving), SMART (Stop Marketing Alcohol on Radio and TV) and CCAA (Citizens Concerned about Alcohol Advertising) in the USA and elsewhere.

However the sale and distribution of liquor has always been recognized as a privilege rather than a right (Wilcox, 1985:34) and therefore has always been subject to government controls covering the production method and content, the place, time and manner of distribution, and the pricing and marketing of alcoholic beverages. The power of the state to regulate the use of alcoholic beverages 'is an incident of society's right to self-protection and it rests upon the right of the state to care for the health, morals, and welfare of the people' (Wilcox, 1985:34).

Restrictions on the marketing and availability of alcoholic beverages are based on the consumption model of alcohol abuse in terms of which alcohol-related problems in a particular society are related to the extent of per capita alcohol consumption in that society (see Wenman, 1981:296). The marketing and consumption of alcoholic beverages have been regulated in almost every country in the world. Thus outright prohibition has been tried in Canada, Finland and the USA (where it still exists in some states) and currently, total and partial prohibitions exist in several Middle Eastern countries (see Fridjhon \& Murray, 1986). Distribution monopolies have been set up in many countries (for example Norway, Sweden and 15 states in the USA) in order to curb the encouragement of consumption which characterizes private enterprise operations (Fridjhon \& Murray, 1986). In Communist countries state monopolies exist as a matter of course.

Complete advertising bans exist in Norway, Finland and most Communist countries, while other countries usually have at least some form of restriction on advertising. Thus France, for example, has a legally imposed code which divides alcoholic beverages into five categories on the basis of increasing alcoholic content. The restrictions on advertising increase with each group until no form of advertising whatsoever is permitted for Group 5 products (see Fridjhon \& Murray, 1986). Restrictions on television advertising of alcoholic beverages exist in Italy and West Germany (in terms of a voluntary code), television advertising is banned in Switzerland, is permitted but regulated in the UK, Luxembourg and the Netherlands (Pridgen, 1985:26). In Canada, regulations differ widely from state to state, from virtually no regulation in Newfoundland to a total ban in New Brunswick (Thompson, 1981:12).

In the USA, ingredients used have to be listed on all beer and liquor containers, and in 1983 the Center for Science in the Public interest (CSPI) called for a complete ban on alcoholic advertisements on the broadcast media; presentation of advertisements stressing the health problems related to drinking; health warnings on print advertisements; a ban on the use of imagery and 'puffery' in advertisements; a ban on the use of celebrities in advertisements, and restrictions on channels of distribution of beer, wine and distilled spirits (Higgins, 1983:1). The CSPI justified its demands on the basis that most self-regulatory advertising codes were 'ineffectual and a farce' and used by advertisers 'primarily . . . to keep from propelling themselves into the public scorn' (Higgins, 1983:4). It criticized the guidelines provided as mirroring practice rather than setting a standard of practice. On the effect of alcohol advertising the CSPI commented: 'Only a very naive person would argue that the massive amounts of sophisticated and expensive marketing efforts do not tend to whitewash the dangers of alcohol by imbuing alcoholic beverages with an image of total harmlessness and by reinforcing drinking as the social norm' (Higgins, 1983:4).

Nineteen American states today hold innkeepers and restauranteers legally responsible for the sobriety of their clients who drive and in another 16 states liability is upheld by case law. New Jersey has ruled that even a private householder may be culpable if his guest leave in a state of intoxication (Barber, 1985). In fact in the USA, with the minimum legal drinking age being raised from 18 to 21 in many states, the campaign against drunken driving has expanded into a debate on the 
role of alcohol in society, and more and more Americans are turning away from alcohol owing to a combination of higher taxes on alcoholic beverages, health concerns and anti-alcohol campaigns ('Americans turning away from Alcohol', 1985).

The effects of advertising and advertising bans on consumption levels are uncertain. As in the case of tobacco advertising, many studies have been conducted and although some believe advertising bans are not really effective in reducing consumption (Kohn, Smart \& Ogborne, 1984; Strickland, 1982; Duffy, 1982), others believe that they are (Higgins, 1983; Wenman, 1981). However, even if advertising bans and controls on availability did reduce the level of consumption in the general population, there is still no unanimity on whether this would reduce the number of alcohol-related problems (Phillipson, 1981:33; Davis, 1981: 270; Rocha-Silva, 1985a:4). Nevertheless, it does appear that as the consumption levels have risen in both Western and Communist countries, the incidence of alcohol-related problems has also risen (Grant, Plant \& Williams, 1983:10).

Greater public concern has also resulted in greater pressure being exerted upon the liquor industry to participate in finding solutions to the problem of alcohol-abuse. The industry in turn, in order to avoid greater regulation, prohibition or even nationalization of its interests, is responding positively to this pressure. Thus many companies have embarked upon social marketing campaigns to encourage the moderate use of their products - the Seagrams Moderation Campaign perhaps being the best known of these, with advertisements headed 'No thanks. I've had enough' and 'Should you drink if you're pregnant?' In addition, many have provided funding for organizations combating drunken driving, medical and social research in alcohol abuse and educational programmes to teach, particularly the young, about alcohol use and abuse.

However, whilst the liquor industry is anxious to be included - and to have a voice - in all deliberations and actions concerning alcohol abuse, it strenuously opposes any solutions which it feels would significantly damage its sales. Thus whilst there are three factors affecting alcohol use and abuse (the user or host, the agent - alcohol - and the environment (Wenman, 1981:289)), the liquor industry generally concentrates upon the user and the environment, and tends - deliberately - to ignore the actual agent (the alcoholic beverage).

This understandable inconsistency is summed up by Hacker (quoted in Higgins, 1983:4) as follows: 'The reaction of the liquor industry has been one of recognising that they've got problems in this area of marketing and also of denying that their advertising or marketing has anything to do with alcohol abuse.'

\section{The South African situation}

In this section the legal environment and the social environment will be treated separately (insofar as this is possible). Because of much that is common in the legal situations of the two industries, they will be treated under one sub-heading. For a discussion of their social situations, however, the two industries will be treated separately.

\section{The legal environment}

The laws governing marketing practice pertain to a very wide spectrum of activities ranging from issues like false advertising to price controls. Whilst most of these laws are relevant to the tobacco and liquor industries inasmuch as they are relevant to most business enterprises, the focus in this sub-section will be upon regulations affecting the promotion - and in particular the advertising - of tobacco and liquor products. Although the common law of South Africa provides protection in delict and contract to those who have sustained damages as a result of fraudulent or negligent misrepresentations in advertisements, the onerous requirements which must be met in order for any such legal suit to be successful as well as the tardiness and expense of such a procedure, make this avenue of recourse practicable in only a few - usually very serious - circumstances (Louw, 1975:100-112).

Statutory protection is provided in terms of the Trade Practices Act 76 of 1976 (as amended by Act 55 of 1980). One of the objectives of this Act is: 'To prevent the influencing of purchasers or users of services by false or misleading statements, either visual or oral'.

Section 9 of the Act deals with the Prohibition of Adverticements and in essence requires that advertisements regarding the sale or leasing of goods or the rendering or provision of any service must not be false or misleading (Sinclair, 1985:107).

Although the above legislation may make litigation easier, it does not give any new civil remedies. Katz (1975: 10) suggested that a body similar to the Federal Trade Commission in the USA which not only regulates and receives complaints, but aiso investigates and imposes penalties, may provide greater protection to the consumer than the kind of protection afforded by the above statute. And in the words of Roome (1976:79): '. . . it is difficult to accept the contention that an avowedly pro-capitalist Government will make indiscriminate use of the measures at its disposal. It is much more likely that the Act will be used merely to curb the activities of what is regarded as the more rapacious element in business and to encourage a greater degree of self-regulation by the various trade and industry associations.'

The main body regulating advertising in South Africa, the Advertising Standards Authority (ASA), has no legislative authority at all. The ASA was established in 1969 in an effort to pre-empt and avoid the imposition of government regulation which appeared imminent at the time. It was successful in this respect and in fact South Africa is today the only country in the world in which a single, voluntarily-imposed regulatory control exists (Sinclair, 1985:36).

The ASA is an independent body set up and funded by the advertising industry 'to ensure that its system of selfregulation works in the public interest' (Preface to the Code of Advertising Practice of the ASA). Sixteen associations and organizations representing every aspect of the marketing industry are members of the ASA and thus required to adhere to its provisions. The ASA has an independent chairman (usually a present or former member of the judiciary), and is administered by a committee constituted of persons drawn from its member organizations.

The Code is, in addition, supplemented by the codes of member organizations such as those of the South African Broadcasting Corporation (SABC) and the Newspaper Press Union (NPU) and 'All such codes conform to the general principles laid down by the Advertising Standards Authority Code and differ only in detail where the individual needs of the medium are to be met'. (Preface to the Code of Advertising Practice of the ASA.)

Thus whilst the ASA cannot require an organization to accept an advertisement which conflicts with that organization's individual code, the ASA may require the organization to withdraw an advertisement which, though acceptable in terms of the individual code, violates the ASA Code. 
'Responsibility for observing the Code rests primarily with the advertiser. But it also applies to any advertising practitioner or medium involved in publication of the advertiser's message to the public.' (Preface to the Code of Advertising Practice of the ASA.)

Sanctions which exist are primarily in the form of a withdrawal of advertising space from advertising practitioners. Another powerful form of sanction is that of adverse publicity, because the ASA has the right to publish details of the outcome of investigations and names of offenders. An essential feature of the ASA is thus its self-regulatory mechanism, and it is in fact the belief of the ASA that 'professional regulations, voluntarily applied, can ensure the elimination of dubious practices more speedily and less costly than government legislation; and are also more easily adaptable to changing economic and social conditions.' (Preface to the Code of Advertising Practice of the ASA.)

The Preamble to the Code sets out the broad principles to which advertisements are required to adhere, such as decency, honesty and legality. Advertisements should also show a sense of responsibility towards the consumer. These broad principles are expanded upon in Chapter II of the Code, but it is only in Chapter III of the Code that cigarette and liquor advertising are specifically mentioned.

Cigarette advertising is dealt with in Appendix $\mathrm{H}$ of the Code. From a perusal of its provisions it can be seen that its provisions are very general, indicating intent (for example, to appeal to existing smokers rather than to increase the number of smokers - Section 2.1) rather than spelling out how this intent is to be achieved. Thus whilst no health claim should be implied by any advertisement (Section 3.6), it is not clear what would constitute an implied health claim. And although advertisements are not to be directed at children or those who are especially vulnerable (Section 2.2), the only explicit regulations in this regard refer to children (i.e. the age of models, the advertising of cigarettes in the immediate vicinity of schools and in family situations and the prohibition on using celebrities who might particularly appeal to those under 18 years of age) - and even these are not particularly restrictive, considering their purpose.

Liquor advertising is dealt with under Section 17 of Chapter III. Again, much the same comments as were made concerning the regulation of cigarette advertising are applicable here. Thus advertisements suggesting an irresponsible attitude towards the consumption of liquor are not allowed (Section 17.4.1) and neither are those which suggest consumption of alcoholic beverages in improper or inadvisable situations (and here some examples - such as motor vehicle driving - are actually mentioned). Again advertisements may not be directed at those below 18 years of age.

As far as the print medium is concerned, the NPU code contains no additional regulations concerning liquor or cigarette advertising and thus it applies the ASA code without exception (Newspaper Press Union of Africa, 1985; pers. comm.). Whilst the SABC does have its own regulations regarding liquor and cigarette advertising, these are substantially the same as those contained in the ASA code (SABC, 1985, pers. comm.). However, there is no advertising of cigarettes or 'hard' liquor such as spirits on television. Despite this, sport sponsorships are an extremely popular form of promotion for both the cigarette and liquor industries, and to the extent that events sponsored by these industries are shown on television, the names of certain brands of cigarettes or liquor may be screened (the SABC allows the sponsors even if they are tobacco or liquor companies - to display their banners and boards prominently) (Clayton, 1985:62). The importance of this type of promotion to the tobacco and liquor companies is indicated by the following comment: 'The best thing any government did for sport was to ban cigarette advertising from television ... Thrown out the front door, the tobacco companies nipped sharply in again at the back, by way of sport.' (Lineberry quoted in Clayton, 1985:79.)

In February 1986, as a result of public pressure, cigarette advertising was withdrawn from the English and Afrikaans radio stations (which had just turned commercial a month previously), although they continue to advertise on all other commercial stations ('Medical Journal calls for ban', 1986).

Further regulation governing the cigarette industry is the requirement that nicotine and condensate levels be printed on all cigarette packets (not as a matter of law but at the request of the Department of Health), and as from September 1986, cigarette packs will also carry the warning 'Smoking is a health risk' in English and Afrikaans. Again, not as a matter of law, but upon the request of the Minister of Health ('Medical Journal calls for ban', 1986).

Unlike the tobacco industry, the liquor industry has its own voluntary industry code regarding sponsorships, advertising and packaging. All liquor companies are signatories to the Code which is administered by the Cape Wine and Spirit Institute (CWSI). The code is similar to the ASA code, but contains certain additional provisions. Among the most pertinent of these is Section 9 which requires advertisements to be compatible with the principle of moderation in consumption, and to this end encourages advertisements which enhance the image of liquor. Section 2 is also significant with respect to the introduction of flavoured wines in that it requires that the packaging of liquor products be such that it does not suggest that the product is similar to a product or beverage appealing particularly to children. Finally, the code contains a section on sponsorships - which should not be such as to encourage the use of alcoholic beverages by children. Apart from this written code there are a number of unwritten agreements regarding packaging and labelling such as that requiring the word 'wine' on packages and bottles of flavoured wine to be a certain minimum size.

It must also be remembered that the supply and distribution of liquor in South Africa is strictly controlled by the Liquor Act 87 of 1977. Indeed, the 'liquor trade in South Africa is subject to more stringent controls than almost all other forms of business enterprise' ('Liquor A Survey', 1984:28). Whilst the basic control mechanism is the system of restrictive licensing, the Act contains a myriad of complex and often outdated measures and regulations. The main control provisions of the Act focus upon the following areas: age and sex of customers and staff; number and density of outlets; hours of sale; alcoholic content; types of beverages; pricing; taxation and criminal law (Fridjhon \& Murray, 1986). It should, however, be noted that the entire Liquor Act is presently under review and the new Act promised in 1987 is expected to do away with many of the restrictions now in existence ('Liquor Survey', 1985:637).

\section{The social context}

\section{The tobacco industry}

In 1984 there were 5542 million smokers in South Africa who consumed 74 million cigarettes per day (United Tobacco Company, 1985:1). In 1984 the total annual advertising expenditure on cigarettes was R37,4 million.

In recent years the anti-smoking lobby in South Africa has become 'more visible and vociferous' (Wallace, 1986). The 
three main participants in the debate are the tobacco industry, the opponents of smoking and the government.

The position of the government is perhaps the most complex because it is faced with a dilemma. As the representative of the public it is obliged, on the one hand, to take cognizance of growing public disapprobation of cigarette smoking and advertising by taking suitable action against these, while on the other hand, the tobacco industry not only contributes enormously to the economy by way of taxes, provision of employment, etc., but also wields great political power in the country. Thus in 1984 Professor Roussouw, president of the South African Nutrition Society, stated that there was a notable absence of anti-smoking legislation in South Africa and he attributed this to vested interests in the tobacco industry. He concluded that it appeared as if money was more important than health to the government (Kleinot, 1984).

Despite its invidious position, the government is being called upon to decrease its reliance on tobacco revenues; to give financial incentives to tobacco farmers to plant needed food crops; to increase its support of anti-smoking campaigns; to give tax rebates to companies which reduce their tobacco production and diversify (Yach, 1982:169).

The medical profession in South Africa has long called upon the government to assist in the campaign against smoking. In 1985 again, the Medical Association of South Africa called for a total ban on tobacco advertising in all media. However in an editorial of the South African Medical Journal ('Cigarette Advertising', 1985), it was recognized that both government and the advertising profession would probably be reluctant to take measures which would be detrimental to their self-interest and thus the medical profession was called upon to take action, for example by boycotting magazines carrying cigarette advertisements. And on 1 February ('A Welcome Reappraisal', 1986:155), it welcomed the withdrawal of cigarette advertising on the English and Afrikaans radio stations. The editorial of the South African Medical Journal stated that while governments had been forced to take action against cigarette advertisements elsewhere in the world, in South Africa little had been done by the authorities in this regard and it concluded that '... if South African public opinion can be mobilised, it can be an effective and powerful force' in opposing cigarette marketing.

Public pressure has indeed become more powerful. In 1978 it compelled tobacco companies to print nicotine and condensate values on cigarette packets (Pleming, 1984) and more recentiy, in 1986, it compelled not only the withdrawal of certain radio advertising as mentioned above, but the carrying of a health warning on all cigarette packs. Many town councils (for example Kimberley and Johannesburg) have been debating the banning of cigarette advertising on all municipal property ('Ban Cigarette Adverts', 1985 and Goosen, 1984). This year the Sandton Town Council is to become the first to ban smoking in all public buildings and restaurants (Openshaw, 1986). In fact Mr William Hefer, ex-mayor of Sandton, is engaged in an ongoing debate with representatives of the cigarette industry which he accuses of 'cynical disinformation typical of the international tobacco industry's approach' ('Ban Tobacco', 1986) and at 'Lulling habitual smokers into complacency' (Hefer, 1986). Mr Hefer goes so far as to call for a ban on tobacco in South Africa ('Ban Tobacco', 1986). Mr Hefer claimed that tobacco is harming more adults in South Africa today than any other drug and said that: "This is the charge the tobacco industry must disprove before it can market its products with a clear conscience' (Hefer, 1986). The tobacco industry has not been passive in response to these criticisms. Thus for example, the United Tobacco Company, whilst agreeing to carry a health warning on its cigarette packs, stated that it felt that the warning ignored the 'scientific and medical controversy concerning the whole question of smoking and health (and failed) to reflect the complexity of the factors and the wide range of views surrounding this controversial issue' ('Medical Journal calls for ban', 1986).

In addition, the Tobacco Board recently launched a campaign to counter the adverse publicity and designed to 'reassure smokers' (Seeman, 1986). In fact the Board has gone so far as to employ a public relations company to run the campaign professionally. The chief spokesman for the industry on these issues is Dr Sarel van der Walt, Research Manager for Rembrandt Tobacco Company, who disseminates information on the possible advantages of smoking in order to provide a balance to what the Board considers is generally 'one-sided or exaggerated generalisations on smoking' (Seeman, 1986). Small groups of journalists are invited to press sessions during which Dr van der Walt presents the arguments in favour of smoking.

A recent Tobacco Board publication summed up the industry's public stance as follows: 'Attacks on smoking are made from time to time. Similar attacks are made on just about every enjoyment of mankind from food to motorbikes and sports. The industry deems it desirable to state its point of view in the interests of those who believe in responsible action as far as personal health and the convenience of others are concerned, while at the same time making allowances for those pleasures which make life worth living' (Seeman, 1986).

\section{The liquor industry}

Whilst South African expenditure on liquor as a percentage of private consumption expenditure is slightly less than the average in world economies, the per capita consumption has increased rapidly over the past decade (Fridjhon \& Murray, 1986). It also appears that South Africa has a substantially higher incidence of alcohol-related traffic deaths than many overseas countries (Rocha-Silva, 1985b:13).

As is the position with cigarette smoking, the government is torn between its own interests and its obligations. As Wenman (1981:303) commented: '.. it is unlikely that government would be favourably disposed towards control measures, which are politically unpopular and may affect its own fiscal interest, unless there is strong evidence of an increase in alcohol-related problems in South Africa which are directly linked to a too liberal attitude towards alcohol availability.'

In addition, the government itself is in fact a part of the industry through its monopoly control of the sorghum beer industry in the country (see 'Liquor A Survey', 1984:15). The powerful Cape wine lobby is also a force with which Government has to reckon and thus it is not surprising to hear the industry criticized for having too much 'privilege and political leverage' ('Liquor A Survey', 1984:7), and the prevailing sentiment appears to be that 'The Cape Wine industry, despite (and perhaps because of) its curiously symbiotic relationship with the government, cannot continue to ignore public concern without courting public outrage'.

Those involved in the prevention of alcohol abuse stress the need for research and education in the area while counselling against an easing of restrictions on availability without very careful consideration of the consequences. This fear arises in the light of government's commitment to deregulation and the promise of a new Liquor Act in 1987 ('Liquor Survey' 1985:637). 
There are also increasing demands by those involved in combating alcohol abuse, for the liquor industry to stress the responsible and moderate consumption of alcohol or otherwise face greater regulation in the marketing of alcoholic beverages.

The level of public concern about the marketing of liquor products has not reached anything like the level of intensity or hostility of that with regard to the marketing of tobacco products. The introduction of flavoured wines into the market in September 1984 did, however, spark off a controversy concerning the social and moral responsibility of liquor marketers, and clearly put the industry in a rather awkward and defensive position - particularly in the light of its own voluntary advertising code and espoused philosophy of responsible marketing.

The industry was accused of packaging flavoured wines in such a way that children would be misled into thinking that they were softdrinks (Ireton, 1984). Furlonger (November 15, 1984), pointed out that one of the reasons for introducing flavoured wines was to introduce new customers to a mild alcoholic beverage so that they would later move to proper table wines and thus increase the consumption of unadulterated alcoholic beverages, much as had occurred in the USA. The newspaper also commented as follows: 'The prime target of the flavoured wine campaign, however, is young people. And that leads to one worrying aspect about the whole operation. Television advertisements for a particular brand of flavoured wine . . . offer it as an ideal thirst-quencher for youngsters surfing or engaged in other energy-sapping activities. The ad shows young people "cracking open" their can of wine and gulping it down just as they would any can of non-alcoholic drink. Although it is an alcoholic drink, the image is a rival of Coca-Cola or Fanta.'

The area in which the greatest public concern is still focused in South Africa is, of course, drunken driving. The National Road Safety Council has, over the past few years conducted a very successful awareness campaign on the consequences of drunken driving and thus, calls for an increase in the minimum legal drinking age and for a reduction in the permitted level of alcohol in the blood, are growing - to the great consternation of the liquor industry. The formation in November 1984 of MADD in South Africa was also significant owing to the extremely influential role it has played in the campaign against drunken driving overseas.

Because its situation is more tenable, the liquor industry has also been less aggressive and less hostile than the tobacco industry. Like its overseas counterparts, it affirms its commitment to the promoting responsible alcohol consumption on the one hand, while on the other, it denies that its marketing may encourage irresponsible consumption or consumption by the young (Ireton, 1984).

\section{Conclusion}

This article has sketched the situations of the tobacco and liquor industries both internationally and domestically. A few general observations can be made:

(i) Legislation concerning both the tobacco and liquor industries is far more extensive and sophisticated in overseas countries than it is in South Africa. Many of the regulations being imposed on, for example the cigarette industry in South Africa now, were imposed upon the cigarette industry in the USA almost 20 years ago.

(ii) Marketing regulations overseas are largely enshrined in law whereas many of the restrictions concerning the marketing - and particularly advertising - of tobacco and liquor products in South Africa are in the form of self-regulation.

(iii) Both the tobacco and liquor industries overseas are encountering greater societal pressures and more hostility than are their counterparts in South Africa (and perhaps this accounts for the differences in type and degree of regulation), although public understanding of, and concern about, the issues has increased considerably in South Africa and is, without doubt, going to continue this way.

(iv) Both internationally and domestically the cigarette industry is being subjected to greater demands and pressures than is the liquor industry, although this difference is perhaps more marked in South Africa than overseas where the public campaign against alcohol and its abuse is gaining momentum very rapidly.

\section{References}

Advertising Standards Authority Code of Practice. Johannesburg: Advertising Standards Authority.

A Welcome Reappraisal. 1986. S. Afr. Med. J. 69, 3, February 1, 155.

Ban Cigarette Adverts - Call. 1985. Diamond Field Advertiser, July 9.

Ban Tobacco, Says Sandton Mayor. 1986. The Star, February 15.

Barber, S. 1985. Real Price of a Drink is Too High. Rand Daily Mail, January 29.

Blakeney, M. \& McKeough, J. 1984. The Right to Advertise. The Cigarette Debate. Media Info. Austr., 31 February, 42-46.

Blum, A. \& Rosenberg, J. 1983. When 'More Doctors Smoked Camels': Cigarette Advertising in the Journal. N.Y. State J. Med., vol. 83, December, 1347-1352.

Boddewyn, J.J. (ed.) 1983. Tobacco Advertising Bans and Consumption in 16 Countries. New York: International Advertising Association.

Cigarette Advertising and the Media. 1985. S. Afr. Med. J., June $29,1,519$

Clayton, B.C. 1985. Corporate Objectives in Sport Sponsorship. Johannesburg: University of the Witwatersrand, (Unpublished MBA Research Report).

Court Battle Over Death of Smoker. 1985. Natal Mercury, July 4.

Cummins, K. 1984. The Cigarette Makers. How they get away with Murder - with the Press as an Accessory. Wash. Monthly, April, 14-24.

Davis, R.D. 1981. Prevention Programmes initiated by the Liquor Industry in the United States of America. In: Alcohol in Perspective. Pretoria: Department of Health and Welfare, (Proceedings of the conference: Alcohol in Perspective, 12-14 October 1981), 267-271.

Doron, G. 1979a. Administrative Regulation of an Industry: The Cigarette Case. Public Admin. Rev., vol. 39, March/April, $163-170$.

Doron, G. 1979b. How Smoking Increased when TV Advertising of Cigarettes was Banned. Regulation, 3, 2, March/April, $49-52$.

Duffy, M. 1982. The effects of Advertising on the Total Consumption of Alcoholic Drinks in the United Kingdom: Some Econometric Estimates. J. Advert., vol. 1, $105-117$

Fenn, 1983. Will the Hill Send Tobacco Packing? The Industries Lobby faces the Heat in D.C. Advertising Age, January 31, M10 - 15

Foundation for Research on Human Behavior, Group Influence in Marketing. 1981. In: Marketing Classics. Enis, B.M. \& Cox, K.K. (Eds.) 4th Edition. Boston: Allyn and Bacon, Inc.

Fridjhon, M. \& Murray, A. 1986. Conspiracy of Giants. The South African Liquor Industry. Johannesburg: Divaris Stein Publishers.

Furlonger, D. 1984. How Flavoured Wines Could Bear Fruit. Rand Daily Mail, November 15.

Goosen, M. 1984. Cigarette Debate in Council. Rand Daily Mail, June 2.

Grant, M., Plant, M.A. \& Williams, A. 1983. Introduction. In: Economics and Alcohol. Grant, M., Plant, M.A. \& Williams, A. (Eds.) London: Croom Helm, 9-11. 
Hefer, W. 1986. Nicotine - The Drug. The Star. March 6. Higgins, K. 1983. Debate Rages over Marketing and Alcohol Problems. Marketing News, 17, 20 September 30, 1-4. International Advertising Association, 1983. Tobacco and Advertising. Five Arguments Against Censorship. New York: International Advertising Association.

Ireton, C. 1984. Disguised Wine May Endanger Children. Sunday Express, November 25.

Jacobson, B. 1983. Smoking and Health: A New Generation of Campaigners. Br. Med. J., vol. 287 (6390), August 13, $483-484$.

Kahn, P.L. 1983. The Minnesota Clean Indoor Air Act. A Model for New York and Other States. N.Y. State J. Med., vol. 83, December, $1300-1301$.

Katz, M. 1975. The Legal Background to Marketing Strategy An Overview. In: Marketing Within the Law - The Facts. Johannesburg: National Development and Management Foundation of South Africa, June, 4-18. (Proceedings of the conference: Marketing Within the Law - the Facts).

Kleinot, P. 1984. Tobacco Industry put before Health, Nutritionists told. The Star, July 11.

Kohn, P.M., Smart, R.G. \& Ogborne, A.C. 1984. Effects of Two Kinds of Alcohol Advertising on Subsequent Consumption. $J$. Advert., vol. 13, 34-40.

Lessof, M.H. 1983. Culpable Negligence: A Case for the Courts? N.Y. State J. Med., vol. 83, December, $1282-1283$.

Liquor A Survey. 1984. Financial Mail, October 26.

Liquor Survey. 1985. Finance Week, November 28 -December 4, $615-640$.

Littlechild, S.C. 1982. Controls on Advertising: An Examination of Some Economic Arguments. J. Advert., vol. 1, 25-37.

Louw, J.R.M. 1975. Marketing Implications of Legislation Affecting Advertising. In: Marketing Within the Law - The Facts. Johannesburg: National Development and Management Foundation of South Africa, June, 100-112. (Proceedings of the conference: Marketing Within the Law - The Facts).

Medical Journal calls for Total Ban on Cigarette Adverts. 1986. The Star, February 7.

Metra Consulting Group Ltd., 1980. The Relationship between Total Cigarette Advertising and Total Cigarette Consumption in the $U K$. January.

More Americans are turning away from Alcohol. 1985. The Citizen, January 7.

Morkel, H.J. 1982. The Problems Associated with the Development of a Non-Smokers Life Assurance Product. Cape Town: University of Cape Town, November. (Unpublished MBA Research Paper).

New Woes. 1983. Advertising Age, January 31, M9-11.

Openshaw, J. 1986. Alcohol in Modern Society. In: Alcohol in Perspective. Pretoria: Department of Health and Welfare, 27-42. (Proceedings of the conference: Alcohol in Perspective, 12- 24 October 1981).

Phillipson, R. 1981. Alcohol in Modern Society. In: Alcohol in Perspective (Proceedings of the conference), Pretoria: Department of Health and Welfare.

Pleming, S. 1984. Smoking Costs SA Millions. The Star, August 9.

Pridgen, D. 1985. Satellite Television Advertising and the Regulatory Conflict in Western Europe. J. Advert., vol. 14, 23-29.
Rocha-Silva, L. 1985a. Alcohol-Related Problems: A Need for Nationally Co-ordinated Social Science Research. Pretoria: Institute for Sociological and Demographic Research, Human Sciences Research Council. (Unpublished article).

Rocha-Silva, L. 1985b. The Prevalence of Alcohol-Related Problems among White South Africans - Some Multi-Source Evidence. Pretoria: Institute for Sociological and Demographic Research, Human Sciences Research Council. (Unpublished article).

Roome, W.B. 1976. The Trade Practices Act in Perspective. Businessman's Law, vol. 5, December 15, 77-79.

Rudolph, B. 1985. Tobacco Takes a New Road. Time Magazine, November $18,76-77$.

Smoking - Changes in Emphasis. 1983. S. Afr. Med. J., November 12, 1, $803-804$.

Smoking Habit Traps More Women. 1986. The Star, July 11.

Sinclair, R. 1985. Make the Other Half Work Too. A Text on Advertising in South Africa. Johannesburg: Macmillan South Africa.

Sobczynski, A. 1985. Marketers Clamor to Offer a Lady a Cigarette. Advertising Age, January 31, M14- 16.

Sobczynski, A. 1985. Is the Youth Market Fair Game? Advertising Age, January 31, M16-17.

Strickland, D.E. 1982. Alcohol Advertising: Orientations and Influence. $J$. Advert., vol. 1, 307-319.

Teel, S.J., Teel, J.E. \& Bearden, W.O. 1979. Lessons Learned from the Broadcast Cigarette Advertising Ban. J. Mark., vol. 43, 1 January, 45-50.

Tobacco Firms Face Sponsorship Threat. 1985. Marketing, March 21.

Tobacco Firm Found Not Guilty. 1985. Evening Post, December 24.

Thompson, A.A. 1982. Phillip Morris Inc. In: Cases in Strategic Management. Strickland, A.J. \& Thompson, A.A. Plano, Texas Business Publications, Inc., 221 - 226.

Thompson, T. 1981. Beer Law: To Each His Own. Advertising Age, October 5, 512.

United Tobacco Company. 1985. The South African Cigarette Market. Internal Marketing Research Document.

Wallace, P. 1986. There's No Smoke Without Fire as World Turns Against Tobacco. The Star, January 13.

Weis, W.L. 1985. A Smoke Cloud Over Tobacco's Future. Bus. Soc. Rev., vol. 52, Winter 37-40.

Wenman, C.H. 1981. Availability of Alcohol. In: Alcohol in Perspective. Pretoria: Department of Health and Welfare, 289-305. (Proceedings of the conference: Alcohol in Perspective, on $12-14$ October.

Wilcox, G.B. 1985. The Effect of Price Advertising on Alcoholic Beverage Sales. J. Advert. Res. October-November, 33-38.

Wilkie, W.L. 1985. Affirmative Disclosure at the FTC: Objectives for the Remedy and Outcomes of Past Orders. J. Publ. Pol. Mark., 91-111.

Wilkie, W.L. 1977. This Product is Not Quite as Good as We Used to Say. Wharton Magazine, 1, 2, Winter, $31-35$.

Yach, D. 1982. Economic Aspects of Smoking in South Africa. S. Afr. Med. J., vol. 62, July 31, $167-170$.

Zeeman, I. 1986. Tobacco Industry Fights Back. Sunday Tribune, February 9. 